\title{
Study on Communication of Characteristics Smart Learning from UX Perspective
}

\author{
Jung-Ae Lee ${ }^{1}$, Tae-Hyung Kim ${ }^{2}$ and Jean-Hun Chung ${ }^{3 *}$ \\ ${ }^{1}$ Ph.D course, Dongguk University, \\ 30,Pildong-ro 1-gil, Jung-gu, Seoul, 100-715,Korea \\ ${ }^{2}$ Gyeongi-Do advisor to the Govemor(ph.d), \\ 1Hyowon-Ro,Paldal-Gu,Suwon City, Gyeonggi Province, Korea \\ 3, *Pofessor, Graduate School of Dongguk University, \\ 30,Pildong-ro 1-gil, Jung-gu, Seoul, 100-715, \\ 1famousis@naver.com,ㄹkimtoja@paran.com, ${ }^{3}$ evengates@gmail.com,
}

\begin{abstract}
Researches on smart learning have so far focused on e-learning contents, infrastructure, and the quality of teaching and learning method.

This thesis based on the stance that, as smart learning is mainly practiced through smart devices people carry with them every day, its platform evaluation should go beyond just simple evaluation of content effectiveness but to more diversified aspects such as users' feeling, association, and difference. And such smart learning analysis and evaluation should be connected to subsequent emotional UX management and brand asset management that serve as strategic guidelines for mobile telecommunication op erators' platform business and e-learning content production.

This study examined more customized functions of mobile telecommunication operators' smart learning platform services currently available in the market by considering the perspective of the emotional UX. By doing so, this thesis sought to make some strategic approaches to create values.

We, for the purpose of this study, selected T-smart learning of SK Telecom, the first South Korean mobile telecommunication carrier to launch a smart learning platform. For case analysis, we employed Yin's theory, adopted the explanation research method to interview involved officials and users and recorded interview details and resulting reports by using the case study method.

In addition, based on previous studies and in the perspective of emotional communication rather than technological perspective of Smart Learning, it drew four categories: (1) interdisciplinary, (2) customized management, (3) motivation, and (4) knowledge network. The characteristics of SK T-learning UX factor was interpreted on the basis of Oral-Formulaic Theory by Ong, Walter J (1995). As a result, it was revealed that oral-formulaic characteristics were found in the Smart Learning factor in the smart environment. Also, it was found that the oral-formulaic characteristics were in the same context with the smart characteristic of smart learning.
\end{abstract}

Keywords: Smart Learning, Orality, User experience, The third orality

\section{Introduction}

Smart technology provided us real-time access to the internet, a virtual space in our daily life, and opportunities to enrich our real lives through SNS, including foundation for

\footnotetext{
* Corresponding Author
} 
website use, free from time and space restraints, by combining a variety of technologies based on Mobile.

IT and infrastructure that develop at such a quick pace create new industries and demands through interdisciplinary convergence, and encourage the field of education to adopt convergence contents equipped with various IT technologies. As learning devices expand its realm from PCs to tablet PCs, smart phones, and mobile media platform, learning environment becomes free from time, space, and devices.

Compared to existing PC-based on-line learning, place for learning changed from fixed area to moving area like the subway and bus, and users include young children and adults, along with students who are familiar with IT devices. And a limited interaction with lecturers turned into real-time communication with teachers, making it easier to discuss with peer group. In addition, digital textbooks boost interactive learning, thus, the way of learning changed from 'the acquisition and accumulation of knowledge' into 'data search and problem solving, share and cooperation'. [1]

Modern UX meets needs in terms of function and has more humane factors, resulting in interaction that provides emotional communication with people.

Recent paradigm shift showed that emotional technology which was related to ICT integration changed from 'sensibility' to 'communication and sympathy'. 'Communication and sympathy' means connection and data sharing in social network among devices or between devices and users in terms of emotional technology, other than mere sociological phenomena. It expands its function from ability to understand and support sensibility to ability to empathize with and share information and feelings, which leads to 'technology of communication' and 'technology of sympathy'. [2]

So far text books have been combined with smart devices in terms of quantitative growth, but in the perspective of lifelong education, pursuing qualitative growth that realizes users' new experience value, the field of education, communication, and devices should not be separated, and User Experience beyond usability is at the center of successful strategies.

In this context, smart learning puts emphasis on experience of communication to accumulate network of knowledge differentiated from conventional PC-based on-line learning. And it is necessary to interpret its evolved form in a new media era.

The purpose of this study is to figure out of UX factors in smart learning, major characteristics of communication factor found in educational paradigm shift on the basis of orality by Ong, Walter J, and analyze the difference between the characteristics and experience in PC-based on-line learning. Also it aims to define relationship between UX and devices of smart learning and contents UI on the basis of this study and use this study as basic information to develop more differentiated learning experience.

\section{Research Method and Range}

This study carried out case analysis of SK T-smart learning in depth, on the basis of Yin' s theory [3]saying like development of UX- oriented smart learning platform, research area which is in a activated phase but lacks typical cases can be studied effectively through qualitative case-study method. Explanation was applied to interviews with relevant people, and case study was applied to analyze the interview contents and associated reports. On the basis of preceding research, 4 categories of UX factor in smart learning were drawn: (1) interdisciplinary, (2) customized management, (3) motivation, and (4) knowledge network. And the study interpreted those 4 categories in view of 'mediation method of language', 'sense system', 'text characteristics', 'temporality', 'existence', and 'interaction method' to analyze communication characteristics in UX factor according to the third orality, compared to conventional PC-based on-line learning. 
The case analysis was analyzed on the basis of the in-depth interviews with relevant people, associated report, literature research, and smart learning service menu, and also used homepages, articles, interviews with others on occasion demands.

\section{Theoretical Background}

\subsection{Review of Preceding Research}

Diverse research on smart learning is being carried out after M-learning and U-learning, but there is little research that focuses on the change of communication in the perspective of evolution, though communication is an important characteristic in smart learning.

Previous studies that thought highly of changing communication characteristics are as follows.

Paul Levinson(2009) called a variety of media forms in the age of Web 2.0 "New New Media"[4], and distinguished them from traditional internet communication where people searched information and sent and received emails. He argued that communication characteristics in 'New New Media' were based on multimedia, interactive connection, and micro contents that users made, and interpreted communication factor in media environment from the evolution of orality's point of view.

Jo do-hyeon(2011) considered the role of media to be the second avatar which helped human nature that pursued connection to others, free from time and space, with diverse people to expand human beings' experience, and he treated communication change in a meaningful way.

As research that made study on form applied with communication in terms of educational characteristics in media environment, Kim myeong-suk(2010)[5] indicated that by using collective intelligence, the form was able to create and developed knowledge collaboratively. And she said internet ecosystem that web users made together has developed organically in its scale and connecity, and stressed network function of interactive communication and information. Internet trend data by Morgan Stanley (Meeker and others, 2010) showed mobile devices played a role in new integrated communication focusing on sharing as seen in the below [Figure 1]

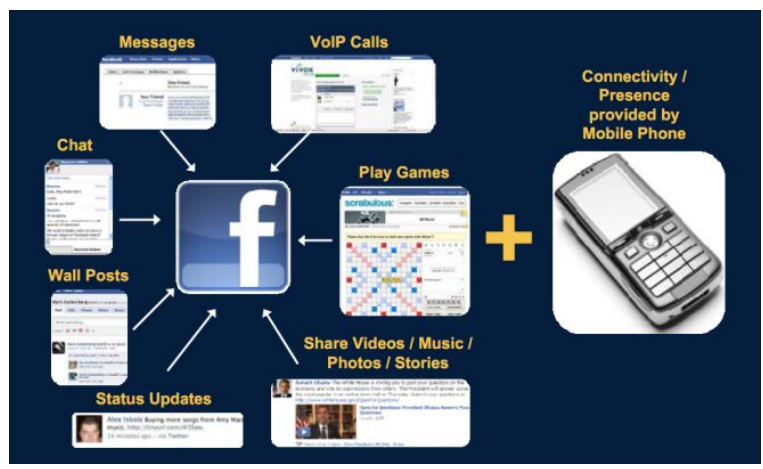

Figure 1. Integrated Communication and Multimedia use (Meeker and others, 2010)

IT strategic report by KT, 'Smart revolution, change the world' [6] put emphasis on communication in the smart era, which is connected and shared all the time, and said that rapidly increasing SNS boosted real-time and interactive communication. And it also thought network as premise of every change and opportunity and called it major infrastructure for future development, as covering future evolution of communication. 
Likewise, the change of new media environment makes relation-oriented network take important task in terms of function and content, which encourages researchers to study the evolution of communication, the foundation of network and relationship building.

\subsection{The Definition and Characteristics of Smart Learning}

In 2011 Ministry of Education, Science, and Technology defined smart learning as intelligent customized learning system for learners in the $21^{\text {st }}$ century to build capacity, which brings about innovation in learning environment, learning contents, learning method, and evaluation.[7]

\begin{tabular}{|c|c|}
\hline Researchers & Definition \\
\hline $\begin{array}{c}\text { Kwak deok-hun } \\
\text { (Korea E-leaming Industry } \\
\text { Association Seminar, 2010) }\end{array}$ & $\begin{array}{l}\text { Effective leaming that is Intelligent customized focusing on learners, based } \\
\text { on advanced ICT, human beings, and contents rather than devices. It } \\
\text { considers various learning types of leamers, increases thinking, } \\
\text { communication, and problem solving skills, and creates opportunities for } \\
\text { cooperative and individual leaming, which makes leaming more exciting. }\end{array}$ \\
\hline $\begin{array}{c}\text { Allyn Radford } \\
\text { (E-learning International } \\
\text { Conference, 2010) }\end{array}$ & $\begin{array}{c}\text { Activities that induce learners to change their behavior by using } \\
\text { independent and intellectual leaming applied with new knowledge and } \\
\text { technology }\end{array}$ \\
\hline $\begin{array}{l}\text { KINSHU } \\
\text { (E-learning International } \\
\text { Conference, 2010) }\end{array}$ & $\begin{array}{l}\text { Smart leaming is not merely another type of learning that uses mobile or } \\
\text { smart devices. The difference between smart leaming and mobile learning } \\
\text { is that smart leaming has a meaning of paradigm, which suggests the future } \\
\text { direction of e-learning. }\end{array}$ \\
\hline $\begin{array}{l}\text { Electronic Newspaper, } \\
\text { (2010) }\end{array}$ & $\begin{array}{l}\text { Smart leaming generally represents learning contents and solutions that use } \\
\text { a smart phone, media tablet, e-book cell phone, etc. By using a range of } \\
\text { advantages of smart devices such as internet connection, location-based } \\
\text { services, and augmented reality it provides services differentiated from } \\
\text { existing e-learning. }\end{array}$ \\
\hline $\begin{array}{l}\text { Noh kyu-seong } \\
\text { (Korea Digital Policy } \\
\text { Society, 2011) }\end{array}$ & $\begin{array}{c}\text { Smart learning is conducted by smart infra and smart way; smart infra } \\
\text { means clouding, network, server, smart devices, and imbedded devices, and } \\
\text { smart way means customization, intelligent, convergence, social learning, } \\
\text { and collective intelligence. }\end{array}$ \\
\hline $\begin{array}{l}\text { Im hoi-seok } \\
\text { (Department of Computer } \\
\text { Education, 2011) }\end{array}$ & $\begin{array}{l}\text { Communication between learners and learners, learners and instructors, } \\
\text { leamers and contents. } \\
\text { General approach that changes the teaching methods and learning from in a } \\
\text { vertical and traditional way into in a horizontal, bilateral, participatory, } \\
\text { intelligent, and interactive way to increase learning effects, by using ICT } \\
\text { that collaboration, participation, open, and sharing are available. }\end{array}$ \\
\hline $\begin{array}{l}\text { Ministry of Education, } \\
\text { Science, and Technology }\end{array}$ & $\begin{array}{l}\text { A new pedagogy required in the 20st's knowledge and information society. } \\
\text { As a supporting system to bring overall change to education system such as } \\
\text { curriculum, assessment, teachers, smart leaming is the best communication. } \\
\text { Human beings- based social leaming and adaptive learning are integrated, } \\
\text { on the basis of environment. }\end{array}$ \\
\hline
\end{tabular}

Figure 2. The Definition of Smart Learning by Scholars [8]

Major characteristics of smart learning suggested by the government and academic circles are as follows. 


\begin{tabular}{|c|c|}
\hline Researchers & Major characteristics of smart leaming \\
\hline $\begin{array}{l}\text { Ministry of Education, } \\
\text { Science, and Technology, } \\
2011\end{array}$ & $\begin{array}{c}\text { To use self-directed, interest, level, aptitude, lots of information, } \\
\text { and information technology }\end{array}$ \\
\hline $\begin{array}{l}\text { Korea Education and } \\
\text { Research Information } \\
\text { Service, } 2011\end{array}$ & $\begin{array}{l}\text { Convenient and effective leaming, effective learning, availability of } \\
\text { knowledge acquisition, knowledge acquisition that adapts to situation, } \\
\text { practical knowledge acquisition about diverse situations, self-directed } \\
\text { learning }\end{array}$ \\
\hline Kim seong-tae, 2010 & Learning paradigm focusing on human beings, creativity, openness \\
\hline Kwak deok-hun, 2011 & $\begin{array}{l}\text { Learner-oriented, intelligent, cooperation, individual, communication } \\
\text { skill, } \\
\text { problem solving skill }\end{array}$ \\
\hline Jang sang-hyeon, 2011 & $\begin{array}{l}\text { Intelligent, customization, self-directed, instructor-learner supporting } \\
\text { system }\end{array}$ \\
\hline Lee su-hee, 2010 & $\begin{array}{l}\text { Sense of reality, immersion, informal learning, cognitive supporting } \\
\text { system, } \\
\text { creative thinking }\end{array}$ \\
\hline Kim don-jeong, 2010 & $\begin{array}{l}\text { Motivation, self-directed, real-time, leaming management, } \\
\text { individualization }\end{array}$ \\
\hline
\end{tabular}

Figure 3. Major Characteristics of Smart Learning defined by Scholars

Though each researcher had different meanings, they classified the change of learning characteristics into 3 factors: (1) the change of communication (2) the change of production, sharing, and combination of information (3) the change of access to information, the change of information use. And they selected learning using smart devices, learner-oriented learning, individual and customized learning, cooperative learning using social network, and optimization of learning results as common major characteristics.

Preceding research defined 11 factors as characteristics of smart learning: (1) intelligent customized learning, (2) cooperative activities, (3) two-way, (4) participation activities, (5) sharing activities, (6) intelligent learning information management, (7) overcome time and space restraints, (8) to create learning information, (9) to use social networking, (10) to use convergence education media, (11) non-linear learning. And by focusing on these 11 factors, the previous studies analyzed UX factors in smart learning in terms of sensibility. [Figure 4] shows whether the 11 characteristics are applied to learning according to its types.

\begin{tabular}{|c|c|c|c|c|c|}
\hline Smart characteristic function & $\begin{array}{c}\text { Traditional } \\
\text { method }\end{array}$ & E-learning & M-leaming & U-leaming & Smart leaming \\
\hline Intelligent customized learning & & & $\Delta$ & $\Delta$ & 0 \\
\hline Cooperative activities & $\circ$ & $\Delta$ & $\Delta$ & 0 & 0 \\
\hline Two-way & & $\Delta$ & $\Delta$ & 0 & 0 \\
\hline Participation activities & $\Delta$ & $\Delta$ & & $\Delta$ & 0 \\
\hline Sharing activities & & $\Delta$ & & 0 & 0 \\
\hline $\begin{array}{c}\text { Intelligent leaming information } \\
\text { management }\end{array}$ & & $\Delta$ & $\Delta$ & 0 & 0 \\
\hline $\begin{array}{c}\text { To overcome time and space } \\
\text { restraints }\end{array}$ & & & & 0 \\
\hline
\end{tabular}




\begin{tabular}{|c|l|l|l|c|c|}
\hline To create learning information & & & & 0 & 0 \\
\hline To use social networking & & & & $\Delta$ & 0 \\
\hline $\begin{array}{c}\text { To use convergence education } \\
\text { media }\end{array}$ & & & & 0 \\
\hline Non-linear learning & & & $\Delta$ & 0 & 0 \\
\hline
\end{tabular}

Figure 4. Experience Provided According to the Types of Learning ( $\Delta$ : available, $\circ$ : use)

\subsection{The Change of Education Paradigm}

Entering to the age of Web 2.0, the development of smart phone or tablet PC made possible for people to connect to social network all the time, with the result that communication, sharing information, learning, cooperative creation activities became available. Especially, social network sites (hereinafter SNS) such as Facebook, Twitter, Blog, and Wiki changed the way of building relations with people and the range or depth of relations, having influence on social structure or the change of value.

Constructivism theory is one of the fields of study to which the academic world have paid attention over past 10 years. Constructivism theory serves as a theoretical background where learner-oriented e-learning can be most effectively realized. And informal learning and social learning are repeated by researchers from constructivism point of view.

Informal learning which doesn't provide knowledge in a formal way gives various and open learning circumstances through off-line and on-line to cultivate voluntary and creative thinking, and capacity to integrate relevant knowledge. Social learning is to maximize learning effects by interacting among learners, between learners [9].

Constructivism draws attention in that constructivism theory will make a contribution to boost learning effects through interaction among learners, between learners and instructors, learners and teaching materials.

Compared to traditional PC-based on-line learning, place for learning changed from fixed area to moving area like the subway and bus, and users range from students who are familiar with IT devices to young children and adults. And a limited interaction with lecturers turned into real-time communication with teachers, making it easier to discuss with peer group. In addition, digital textbooks activates interactive learning, with result that learning methods changed from 'the acquisition and accumulation of knowledge' into 'data search and problem solving, share and cooperation'.

\subsection{UX Factor in Smart Learning}

While the past UX means technology that improved usability by supporting function, the modern UX satisfies needs in terms of function and has more humane factors, which leads to interaction that provides emotional communication with people.

Recently paradigm shift showed that emotional technology which was related to ICT integration changed from 'sensibility' to 'communication and sympathy'. [10]

Unlike UX that was analyzed, mainly focusing on function, UX factor in smarting learning has emotional factor and functional factor in one experience, so UX factor should be drown as emotional UX structure.

Under communication environment among devices, there are changes of user's needs, customer activities, and movements, which brings about the change of needs again.

Therefore, regarding UX factor, it is necessary to draw a new type of users' experience from 'understanding users' after analyzing users' experience. 


\subsection{The Orality in the Age of New Media}

Orality is the oldest form of communication which has remained and changed constantly. It was not replaced or denied as the new media developed. [11]

Ong, Walter J. (1995) stressed that new media culture developed in a relationship with existing media culture. In other words, letter culture which was standardized had difficulty of expression. However, the media change and different machines had the characteristics of orality applied to letters, which was defined as 'the second orality' by Ong. But he considered media to be linguistic form to realize reality so slightly neglected digital media's way of (re)constructing users' perception, experience, and expression, or interactive pattern that users received and interpreted media. [12]

Text in the era of Web 2.0 that the second orality text is sent as part of it or used in a new from like a radio or television is based on literacy and the second orality[13], but 'New New Media' age shows signs that our communication method changes, and the way of building relationship with the world is reconstituted. Experience of interactivity which is a new communication pattern can be interpreted by the third orality. [13]

The third orality by Lee dong-hu is explained as follows.

Firstly, expression pattern of language use different combinations of voice, text, voicevideo which were the base of the first orality, literacy, and the second orality. Secondly, the third orality text, through hyper text and network connectivity, gets out of linearity and fixity that printed text had, and revives liquidity and dynamicity of oral tradition. Thirdly, the third orality makes it possible to experience simultaneity of oral dialogue or communication similar to the second oral dialogue and read situational experience of communication distant from text. Fourthly, the producers and users of the third oral text coexist through interconnected network. Fifthly, the writers of the third oral text is sensitive to response like the narrator of oral dialogue, and is able to convey message that is closely related to situations. [Figure 5] compares the second orality with the third orality.

\begin{tabular}{|c|c|c|}
\hline Item & The second orality & The third orality \\
\hline $\begin{array}{l}\text { Mediation method of } \\
\text { language }\end{array}$ & Voice, video & Voice, letter, video, multimedia \\
\hline Sense system & audiovisual & audiovisual \\
\hline $\begin{array}{l}\text { The characteristics of } \\
\text { text }\end{array}$ & $\begin{array}{l}\text { Intentional Institutionalized } \\
\text { expressions, collective } \\
\text { narration }\end{array}$ & $\begin{array}{c}\text { Hyper text, liquidity/transformability, } \\
\text { connectivity/permanence, individual/collective } \\
\text { narration }\end{array}$ \\
\hline Temporality & $\begin{array}{l}\text { To focus on present, } \\
\text { simultaneity }\end{array}$ & Simultaneity/non-simultaneity reversibility \\
\hline $\begin{array}{l}\text { Existence of 'you } \\
\text { and me' }\end{array}$ & $\begin{array}{l}\text { Mediated existence, } \\
\text { conscious producer/ } \\
\text { invisible user } \\
\text { Common sense } \\
\text { (region/global) }\end{array}$ & $\begin{array}{c}\text { Existence connected by network } \\
\text { 'me’ as writer-reader common sense(global) }\end{array}$ \\
\hline $\begin{array}{l}\text { The way of } \\
\text { interaction }\end{array}$ & $\begin{array}{l}\text { Planned performance } \\
\text { Common behavior } \\
\text { asymmetric }\end{array}$ & $\begin{array}{c}\text { Self-conscious performance individual/common } \\
\text { writing and reading } \\
\text { symmetric }\end{array}$ \\
\hline
\end{tabular}

Figure 5. The Third Orality 


\section{Case Study}

\subsection{The Standard and Method of Case Study}

This study carried out in-depth case analysis of SK T-smart learning, on the basis of Ying' s theory that like development of UX- oriented smart learning platform, research area which is in a activated phase but has few typical cases can be investigated effectively through qualitative case-study method. Explanation was applied to interviews with relevant people, and case study was applied to analyze the interview contents and associated reports. On the basis of preceding research, 4 categories of UX factor in smart learning were drawn: (1) interdisciplinary, (2) customized management, (3) motivation, and (4) knowledge network. And the study examined those 4 categories in view of 'mediation method of language', 'sense system', 'text characteristics', 'temporality', 'existence', and 'interaction method', and then interpreted communication characteristics in UX factor by using the third orality, compared to conventional PC-based on-line learning.

\subsection{Case Selection and Data Collection}

Case selection was limited, for professionalism and reliability, to (1) cases conducted by professional processes or organizations and (2) cases applied with professional processes or methodology. According to this, on the basis of the platform of SK telecom, a communication platform company, in April 2012, T-Smart learning was chosen as a research subject that was the first service in this industry. Case study was analyzed based on in-depth interviews with people in charge, relevant report, literature research, and service test, along with home pages, news release, and other associated people if needed.

\subsection{Emotional Perspective UX in Smart Learning}

First, [Figure 6] reconstitutes emotional UX items based on characteristic experience in smart learning

\begin{tabular}{|c|c|}
\hline Characteristic function of smart learning & Sensibility-based UX \\
\hline Create learning information & \multirow{2}{*}{ Integrated educational experience } \\
\hline Non-linear learning & \\
\hline Intelligent customized learning & \multirow{3}{*}{ customized management experience } \\
\hline To overcome time and space restraints & \\
\hline Intelligent learning information management & \\
\hline Cooperative activities & \multirow{4}{*}{ Motivation experience } \\
\hline Two-way & \\
\hline Participation activities & \\
\hline Sharing activities & \\
\hline To use social networking & \multirow{2}{*}{ knowledge network experience } \\
\hline To use convergence education media & \\
\hline
\end{tabular}

Figure 6. Emotional Perspective UX in Smart Learning

\subsection{Orality caused by UX Characteristics in T-Smart Learning}

T-Smart learning is an educational application and contents that can be used on OSbased Tablet PC, in a form of Launcher. It provides selected educational contents from 
one Launcher, including learning management that considers levels and character, useful learning tools, and communication experience supporting learning.

[Figure 7] contains experience factors that learners can use, and the experience factors are organically connected, giving out-of-order progress to learners, according to learners' needs.

\begin{tabular}{|c|c|c|c|}
\hline menu & details & content & Smart characteristics \\
\hline \multirow{6}{*}{ home } & Personal learning status & \multirow{6}{*}{$\begin{array}{l}\text { Quick access, mark recent } \\
\text { data }\end{array}$} & \multirow{6}{*}{$\begin{array}{c}\text { To create learning information, } \\
\text { Intelligent learning information } \\
\text { management, } \\
\text { Two-way }\end{array}$} \\
\hline & Topi & & \\
\hline & Photo & & \\
\hline & Class tip & & \\
\hline & Learning contents & & \\
\hline & Learning & & \\
\hline \multirow{5}{*}{ My class } & My class information & \multirow{5}{*}{$\begin{array}{l}\text { Overall management of } \\
\text { class and learning }\end{array}$} & \multirow{5}{*}{$\begin{array}{l}\text { Intelligent learning information } \\
\text { management, } \\
\text { Two-way }\end{array}$} \\
\hline & $\begin{array}{l}\text { Learning setting } \\
\text { Scheduling }\end{array}$ & & \\
\hline & Learning status & & \\
\hline & Learning results & & \\
\hline & Inquiry & & \\
\hline store & $\begin{array}{l}\text { Distinguish categories } \\
\text { according to types }\end{array}$ & $\begin{array}{l}\text { A variety of learning } \\
\text { materials }\end{array}$ & $\begin{array}{c}\text { Convergence, } \\
\text { Use education media }\end{array}$ \\
\hline \multirow{6}{*}{ community } & My community & \multirow{6}{*}{$\begin{array}{c}\text { Organic sharing of } \\
\text { information with learners } \\
\text { who are connected to } \\
\text { network }\end{array}$} & \multirow{6}{*}{$\begin{array}{l}\text { Cooperative activities, } \\
\text { Two-way, } \\
\text { Participation activities, } \\
\text { Sharing activities, } \\
\text { To use social networking, }\end{array}$} \\
\hline & Smart learning zone & & \\
\hline & Smart class & & \\
\hline & Hall of fame & & \\
\hline & Sharing information & & \\
\hline & Customer service center & & \\
\hline \multirow{4}{*}{$\begin{array}{l}\text { Learning } \\
\text { tools }\end{array}$} & Book & \multirow{4}{*}{$\begin{array}{l}\text { Collection of tools } \\
\text { necessary for learning }\end{array}$} & \multirow{4}{*}{$\begin{array}{l}\text { To overcome time and space } \\
\text { restraints }\end{array}$} \\
\hline & Photo & & \\
\hline & Video & & \\
\hline & Writing instruments & & \\
\hline \multirow{6}{*}{ learning } & Understanding contents & \multirow{6}{*}{$\begin{array}{l}\text { Access to downloaded } \\
\text { contents }\end{array}$} & \multirow{6}{*}{$\begin{array}{c}\text { Intelligent customized learning, } \\
\text { To use social networking, } \\
\text { Two-way, } \\
\text { Non-linear learning }\end{array}$} \\
\hline & Repetition & & \\
\hline & Test & & \\
\hline & Evaluation & & \\
\hline & Wrong answer note & & \\
\hline & Expanding learning & & \\
\hline \multirow{7}{*}{$\begin{array}{l}\text { Learning } \\
\text { type }\end{array}$} & Video & \multirow{7}{*}{$\begin{array}{l}\text { Effective and voluntary } \\
\text { choice suitable for time } \\
\text { and space }\end{array}$} & \multirow{7}{*}{$\begin{array}{c}\text { To create learning information, } \\
\text { Non-linear learning, } \\
\text { To overcome time and space } \\
\text { restraints, } \\
\text { To use convergence education media, } \\
\text { Two-way }\end{array}$} \\
\hline & Game & & \\
\hline & Taking notes & & \\
\hline & Record & & \\
\hline & Listening & & \\
\hline & Input & & \\
\hline & sharing & & \\
\hline
\end{tabular}

Figure 7. Main Menu of T-Smart Learning 
Experience factors provided by T-smart learning are classified into 3 categories.

(1) Personal service experience that gives contents based on learners' levels

(2) Experience that uses necessary function and tools by using tablets

(3) Delivery and sharing of information among teachers, parents, and learners through connectivity

On the basis of theory of orality, characteristic factors in smart learning were analyzed. And it was found that most of the characteristic factors were applied to each item.

4.4.1. Interdisciplinary Experience: Interdisciplinary experience that creates learning information and includes non-linear learning makes it possible to register learning information with link and to learn in a non-linear way by creating, editing, registering, and reviewing learning information. This experience also helps learners to establish 'self' as a writer/reader, and to make more active and intentional learning performance.

In addition, it provides diverse multimedia factors that are combinations of letters, voice, and videos, and gives learners opportunities to choose any types that they want. [Figure 8] shows the contents of orality found in these experience factors.

\begin{tabular}{|c|c|c|}
\hline UX factor & Tcreen & The third orality \\
\hline $\begin{array}{c}\text { To create } \\
\text { learning } \\
\text { information, } \\
\text { non-linear } \\
\text { learning }\end{array}$ & $\begin{array}{c}\text { A variety of audiovisual factors using voice, letters, } \\
\text { videos, and multimedia }\end{array}$ \\
$\begin{array}{c}\text { Hyper text and real-time postings induce group } \\
\text { discussion Get out of linear learning } \\
\text { By applying personal network to on-line, }\end{array}$ \\
establish 'self' as writer-reader and induce intentional \\
performance
\end{tabular}

Figure 8. Integrated Education Experience and the Third Orality

4.4.2. Customized Management Experience: it includes intelligent customized learning, to overcome time and space restraints, and intelligent learning management which are concentrated into categories related to learning.

Posting books, photos, and videos enables learners to use past postings as present learning tools and materials. And the experience has simultaneity that gives learning materials to learners according to personal learning progress.

Learning shows a variety of characteristics of orality. Through hyper text and network connectivity, it gets out of linearity and fixity that printed text had, and gives real-time feedback. It can also change reaction into text according to situations. Producers and users coexist through interconnected network. And it provides customized learning for each individual by using experience that conveys messages closely related to situations, as shown in [Figure 9]. 


\begin{tabular}{|c|c|c|}
\hline UX factor & screen & The third orality \\
\hline $\begin{array}{l}\text { Intelligent customized } \\
\text { learning }\end{array}$ & 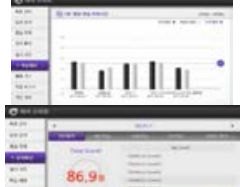 & $\begin{array}{l}\text { To provide voice, letters, videos, multimedia information, } \\
\text { Intimate and precise communication connected to hyper } \\
\text { text }\end{array}$ \\
\hline $\begin{array}{l}\text { To overcome time and } \\
\text { space restraints } \\
\text { Intelligent learning } \\
\text { information management }\end{array}$ & 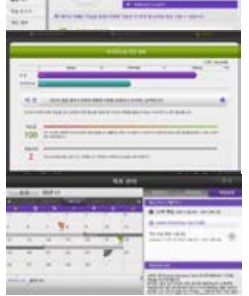 & $\begin{array}{l}\text { To accept roles to plan and do leaming at the same time, } \\
\text { Interaction through individual/common wiring and } \\
\text { reading } \\
\text { To induce intentional performance of learners, free from } \\
\text { time and space restraints }\end{array}$ \\
\hline
\end{tabular}

Figure 9. Customized Experience and the Third Orality

4.4.3. Motivation Experience: It includes cooperative activities, two-way, participation activities, and sharing activities. And it encourages learners to share their learning results and goals with their off-line acquaintances (friends, parents, teacher, etc.,) so that their learning motivation is raised, as shown in [Figure 10].

\begin{tabular}{|c|c|c|c|c|}
\hline UX factor & \multicolumn{3}{|c|}{ screen } & The third orality \\
\hline $\begin{array}{c}\text { Cooperative } \\
\text { activities } \\
\text { Two-way } \\
\text { Participation } \\
\text { activities } \\
\text { Sharing activities }\end{array}$ & 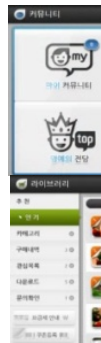 & 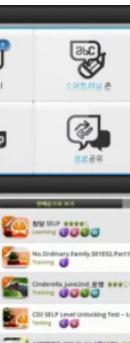 & 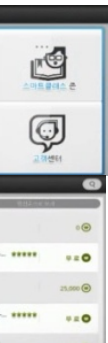 & $\begin{array}{c}\text { To invigorate community such as goal setting, } \\
\text { participation activities, and group discussion } \\
\text { after searching learning progress and flow of } \\
\text { other learners }\end{array}$ \\
\hline
\end{tabular}

Figure 10. Motivation Experience and the Third Orality

4.4.4. Knowledge Network Experience: It is divided into to use social networking and to use convergence education media. Regarding social networking use, space for sharing information and space for communication are created that attract acquaintances and people who learners will never meet in reality.

This kind of relationship building leads to self-directed learning and driving force to make existence linked to off-line meetings.

It shows existence connected to network in terms of orality.

Learners can share various learning fields with various experts by sharing personal learning status rather than learn only one unit that they choose. And information that learners create can be used as another learning materials, as shown in [Figure 11.]. 


\begin{tabular}{|c|c|c|}
\hline UX factor & screen & The third orality \\
\hline $\begin{array}{c}\text { To use social } \\
\text { networking } \\
\begin{array}{c}\text { To use convergence } \\
\text { education media }\end{array}\end{array}$ & $\begin{array}{ccc}\text { To share personal connections and information linked to } \\
\text { network, Opportunities for future learning information }\end{array}$ & $\begin{array}{c}\text { To provide a various kinds of learning materials } \\
\text { and fields }\end{array}$ \\
\hline & & \begin{tabular}{c} 
To improve self-conscious performance, motivation \\
\hline
\end{tabular}
\end{tabular}

Figure 11. Knowledge Network Experience and the Third Orality

\section{Conclusions and Implications}

This study investigated communication factors of UX which are important to smart learning.

Smart learning works out on the basis of communication technology that allows effective real-time interaction.

When interpreted in terms of orality in the age of new media, learning technology of communication has the same context, prepared for the change of media. Its details are as follows.

First, interdisciplinary factors use various audiovisual materials made of voice, letters, videos, and multimedia, and induce group discussion through hyper text and real-time postings. They are far from typical linear learning. They encourage learners to establish 'self' as writer-reader and do intentional performance.

Second, customized factors make it possible to choose various types of learning materials, free from time and space restraints. Through them, intimate and precise communication is available which is connected to hypertext. Learners agree to play a role in both planning and doing learning. And they communicate with others, as interacting through individual/common writing and reading.

Third, in motivation factors, learners set goals and do participation activities after searching other learners' learning progress and flow. And they have factors to activate community such as group discussion.

Fourth, knowledge network factors enable learners to share personal connections and information with others so that they get learning information. They provide various types of learning materials and fields and boost motivation and intentional performance of learners.

The researchers of this study figured out the above four results indicated that smart learning had communication characteristics of UX in terms of orality.

Also such orality evolution suggests that the evolution is part of evolution of communication technology used in modern media and is closely related to development direction of network. Also for active participation of users, active use of availability of communication can make a successful contribution to create a new learning environment model in terms of infra structure, teaching method, and timing of technology development.

\section{References}

[1] “Samsung Economic Research Institute”, the impact of tablet PC and the change of media, (2010).

[2] Y. Myeong-hwan, "The future of TV UX: the communication between sensibility and technology", (2012), pp. 9.

[3] K. Yin, “Case Study Research Design and Methods”, Revised Edition, Sage Publications, (1989).

[4] Paul Levinson, (2009).

[5] K. Myeong-suk, "Learning media in the age of e-Learning 2.0", Book Korea, (2010).

[6] K. T. Digieco, "Smart revolution, change the world".

[7] Way to a talented people power Strategic action program for promoting smart education (plan)- Ministry of Education, Science, and Technology, (2011). 
[8] Quality management of smart education contents and Teaching learning model development issue.

[9] G. Il-sang and G. Yoon-jeong, (2006).

[10] The future of TV UX: the communication between sensibility and technology-Yoon myeong-hwan.

[11] L. Dong-hu, “The third orality”, Press and information research, (2010).

[12] K. B. Jensen, "Mixed media: From digital aesthetics toward general communication theory”, Northern Lights, vol. 5, no. 1, (2007), pp. 7-24.

[13] L. Dong-hu, "Media-philosophical consideration of mobile communication”, future research based on digital convergence, (2010).

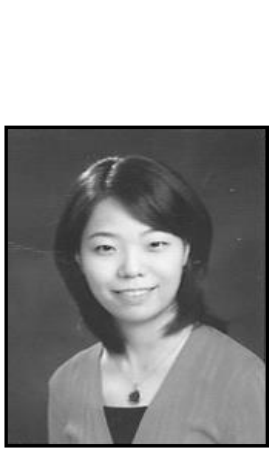

\section{Authors}

\section{Jung Ae Lee}

Ph.D course, Department of Contents Design, Graduate School of Media, Dongguk University

Assistant Professor, Department of Design, Kyungdong University, Field of study: Web, Mobile UX

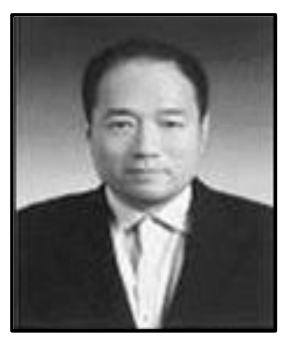

\section{Tae-Hyung Kim}

Gyeonggi-do Information Assistant

Adjunct Professor, Department of Contents Design, Graduate School of Media, Dongguk University

Field of study: Stereoscopic image, Information media policy

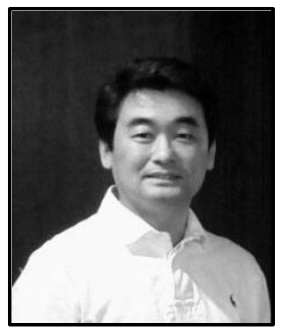

\section{Jean-Hun Chung}

Professor, Graduate School of Digital Images \& Contents Dongguk University (Seoul, Korea)

Field of study: Computer Arts, Contents Design, Computer Animation, Visual Effects. 
International Journal of Smart Home

Vol.7, No.6 (2013) 